\title{
Innovation Ability Cultivation of Automation Major Students
}

\author{
Yanqin Wang ${ }^{1,2, a}$, Weijian Ren ${ }^{2, b}$, Fengcai $\mathrm{Huo}^{2}$, Chaohai Kang ${ }^{2}$ \\ ${ }^{1}$ Institute of Electrical and Information Engineering, Northeast Petroleum University, Daqing, \\ 163318,China \\ ${ }^{2}$ School of Physics and Electrical Information Engineering, Daqing Normal University, Daqing, \\ 163712, China

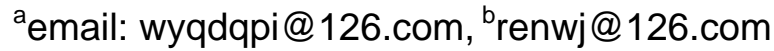

Keywords: Automation; Innovation Ability; Cultivation

\begin{abstract}
Nowadays in China, university education is gradually shifting from elite education to mass education. The amount of college graduates increases rapidly, in order to improve students' competitiveness in the fierce competition, the cultivation of innovation spirit and innovation ability is of crucial importance. The exploration and practice of automation major students' innovation ability cultivation in Northeast Petroleum University is introduced in this paper. By Setting up innovation education concept, building innovation experiment platform, constructing teaching staff and building innovation team, students' innovation thinking, innovation spirit and innovation ability is cultivated. We have obtained preliminary achievement on cultivating automation innovation talents. The results during the past few years show that students' innovation ability is promoted.
\end{abstract}

\section{Introduction}

The 18th CPC National Congress report put forward, "Fully implementing quality education, deepen the comprehensive reform in education field, strive to improve the education quality, cultivating students' social responsibility, innovation spirit and practice ability." Innovation is the soul of a nation's progress and the driving force for the prosperity of a country. Talents are the key to scientific and technological innovation, while colleges and universities are the main lands to cultivate innovation talents. Automation is at the forefront of science and technology and is inseparable with computer and communication technology. Automation knowledge update so rapidly that it has higher demands for personnel cultivating specification. Automation of Northeast Petroleum University is national characteristic specialty. We have done a series of exploration and attempt, including the innovation education idea, innovation platform construction, the innovation teacher team construction, innovation team construction etc. in order to promote the process of innovation talents cultivation.

\section{Set Up Correct and Advanced Concept of Innovation Education}

Ideology of innovation talents cultivation is the core and soul of cultivating creative personnel[1]. To cultivate innovation talents in colleges and universities, we must establish correct, advanced concept of innovation education.

Our China's school education pays more attention to imparting knowledge, and the evaluation to students is based on how much knowledge he or she masters, but ignores the cultivation of students' potential and innovation ability. In talent cultivating scheme, more emphasis was tend to be put on knowledge structure and relatively neglects ability cultivating, especially creative ability and skills. Teacher-centered teaching mode focuses on imparting knowledge and emphasizes the students' learning results, so it can only make the students accept knowledge passively and negatively, lack of interest and passion of exploring issues. To a great extent, this restricts the students' innovation thinking and the cultivation of innovation spirit and innovation ability.

Students are the main body of innovation talent cultivation. Therefore, we must adhere to the student-centered concept, and respect students' subjectivity and personalization. According to the 
principle of "people-oriented, teaching in accordance with students' aptitude" and the law of innovation talents, we build innovation talents cultivation mode which is dominated by "individualized learning" to stimulate students' enthusiasm and innovation potential. According to students' learning interest and ability, we help students independently determine the professional direction, independently design knowledge structure, and independently choose learning mode, let the students fully enjoy the pleasure of autonomous learning, so that they can give full play to the initiative and enthusiasm in the learning process.

We advocate inquiry learning. This can make students experience the process of knowledge generation and formation. It also can make students learn to use their mental work independently, thus the knowledge gained through inquiry is constructed actively by themselves. The inquiry process poses a challenge to the students' thinking, which requires integrated use of the existing knowledge and experience. At the same time, inquiry learning is conducive to protect the students' curiosity and cultivate the students' interests and personality.

Students' innovation spirit, innovation thinking and innovation ability cultivation is put on a prominent position. We shift focus from merely imparting knowledge to cultivating students' ability of independent thinking, asking questions, analyzing and solving problems etc., through which promote the transformation of teaching contents, teaching methods and the management system. We also innovate teaching methods and curriculum, and strengthen the proportion of practical teaching link in course system. Students are encouraged to apply what they have learned to innovate.

\section{Innovation Experiment Platform and Production-Study-Research Cooperation Base}

Colleges and universities are important fields of science and technology innovation, and laboratories are important platforms of innovation talents cultivation[2][3]. Most innovation activities in universities are done in laboratories[4]. In addition to cultivating students' basic experiment ability, aiming at training their innovation thinking and comprehensive ability, automation major imported a batch of laboratory equipments of high and new technology and transformed some laboratories. A fundamental, advanced and open automation experiment teaching platform was built, which includes 2 provincial-level key laboratories "Oil and gas control and dynamic monitoring" and "oil and gas information and control". Now we have formed an open practice teaching system of three levels, basic theory and experimental skills, course design and graduate design, scientific research training and innovation activities.

In the basic theory and experimental skills link, we reduce the verification experiments and increase comprehensive and designing experiments. So that the students' basic experiment skills and methods are trained and the students' ability of comprehensive analysis to the system is improved. More than $85 \%$ of Curriculum design and graduate design topics are from cooperation with factories and fund projects, ensure that students are close to actual production in this comprehensive training link. In scientific research cultivation and innovation activities link, undergraduate students participate in teachers' scientific research project teams, this makes them really involve in the scientific research and preliminary master scientific research methods. Students are encouraged to participate in all kinds of competitions and technological innovation activities.

Production-study-research cooperation is an important approach to cultivate innovation talents. We are closely linked with enterprises in Daqing, and actively develop university-enterprise cooperation. Now we have established more than 10 close off-campus practice bases, which provide convenient conditions for us to realize production-study-research cooperation. By means of university-enterprise cooperation we established "oil production process optimization control technology research and development centers". We now have 10 state-level scientific research projects, 14 provincial projects, more than 30 technology development projects which serve Daqing. More than $80 \%$ of the projects are from the petroleum and petrochemical enterprises.

\section{Construction of The Teaching Staff}

Teaching staff with innovation spirit, innovation thinking and innovation ability and being keen 
on innovation talents cultivation work is the key to cultivate innovation talents in universities.

1. Increase the proportion of teachers with overseas study experience

In order to strengthen the students' international vision and sensitivity to issues at the forefront of industry, we continuously transfer teachers to go abroad for further study and academic exchanges, they participate in international scientific research project cooperation and degree education of other countries, such as a visiting scholar. So that they can have extensively international communication background, and the teachers' internationalization outlook is broadened. By now we have transported a number of teachers to Hong Kong, Britain, Germany, etc. to study abroad or to be a visiting scholar, which have laid a foundation for cultivating innovation talents.

2. Increase the proportion of teachers who have experience in enterprises or research institutes

Through participating in enterprise engineering project or research and development projects, teachers obtain more abundant experience of engineering practice. At present, $40 \%$ of the professional teachers are with engineering or research and development experience. Encourage those who have innovation ability and innovation consciousness in enterprises and research institutes to teach in colleges and universities. Relying on Daqing Oil-field Co., LTD and Daqing Petroleum Administration Bureau, senior engineering and technical personnel are hired as enterprise teachers to run relative courses and guide internship and practice, graduation designing etc.

3. Support teachers in participating in research projects

Teachers' innovation practice ability is enhanced in scientific research work. We encourage teachers to apply for scientific research projects positively and provide convenient conditions for teachers carrying out them. Teachers are encouraged to introduce their scientific research achievements into class to promote the transformation of scientific research to teaching practice. Now our professional teachers undertake 32 scientific research projects of all kinds in the level of nation, province, ministry and university.

4. Improve teacher evaluation system

Teacher evaluation system is the hub and key to coordinate teachers' teaching and scientific research work. In the evaluation system, we must give consideration to both teaching and scientific research to promote teachers to balance them and realize the transformation from scientific and technological innovation ability to innovation talents cultivation ability. Establish perfect incentive system and give priority to these teachers' title assessment to stimulate the teachers who are innovative and have obtained certain achievement continue to blaze new trails to cultivate more innovation talents with more passion and enthusiasm.

\section{Strengthen Innovation Team Building}

International cooperation of scientific research and the rise of big research projects, brought unexpected rapid development to science and technology, it also dramatically expanded the scope of basic research, creativity and complexity. Technological innovation behavior presents the trend of transition from individual innovation to team innovation. Collaborative innovation is both the inherent requirement of development of science and technology progress, and the inevitable requirement of cultivating top creative talents[5]. Relying on "Control Theory and Control Engineering" provincial-level key discipline and "Automation" national characteristic specialty, "Oil and Gas Information and Control Engineering Team" has been built as provincial-level scientific and technological innovation team, and "Control Theory and Its Series Courses Teaching Team" as university-level excellent teaching team.

Strengthen college students' science and technology innovation team building and improve the level of innovation ability cultivating. Relying on innovation experiment platform and production-study-research cooperation base, students innovation teams take part in teachers' scientific research projects, solve enterprises' practical problems and take part in all kinds of competitions etc. Through these activities, students' ability of solving practical problems is enhanced, their innovation ability and team cooperation spirit is cultivated.

The construction of innovation team is a long-term, scientific and rational process, it is also a complicated system engineering. To build a high level scientific research innovation team, we must 
strengthen the institutional construction. We must establish incentive mechanism with hierarchy and pertinence and performance evaluation system. Arousing the enthusiasm of members to strengthen the construction of team culture and build a team of high cohesion and of high belonging sense. We also must guide the team develop healthily and orderly. By enhancing innovation team building drives the cultivation of innovation talents.

\section{Conclusion}

Improving students' practical ability and innovation ability is both economic and social development requirements for personnel qualities and the demand of students' self-development. It also enhances students' employment competitiveness. Aiming at cultivating students' ability of practice and innovation, automation major continuously promote the reform of talent cultivation model over the years. Engineering and innovation education idea is penetrated in the main teaching link, students' practice and innovation ability cultivation is enhanced. The teaching mode is formed which cultivates students' practice ability in laboratories, cultivates innovation ability through scientific research, and cultivates engineering ability through enterprise projects. This major has become an important base of control class talents cultivation and scientific research of domestic petroleum and petrochemical enterprises. Not only oil enterprises but also the large-scale enterprises throughout our country recruit our graduates, which further expands the influence of this major. Graduates are widely welcomed by employing unit, and the employment rate is over 95\%. Students take an active part in all kinds of competitions. 8 students won awards in the National College Students' Physics Competition, 4 in the National Undergraduate Electronic Design Contest, 3 in the National College Mathematical Modeling Contest. 17 college students innovation experiment programs were approved, including 9 national innovation experiment programs. Though we have obtained preliminary achievement on cultivating automation innovation talents, the path of innovation education has only the beginning, no end. Only by continuously exploring and reforming, can we cultivate more innovation talents for our country.

\section{Acknowledgement}

This work is supported by the Key Topics of 2011 Education Science Planning Issues in Heilongjiang Province (Project NO.GBB1211015) and National Intensive and Characteristic Majors Construction---Automation. It is also supported by Teaching Research Issue of Daqing Normal University (Project No.JY1225).

\section{References}

[1] Yao Liu, “Teaching Ideas That Innovative Talent Training Need Change”, China Higher Education, pp. 45-47, January 2010.

[2] Tong Qing Wu, Nian Chun Xu, Lin Qing Huang, "Research Experimental Teaching System Based on Innovative Practice Ability” Advanced Materials Research, vol. 671 - 674, pp.3248-3252, March 2013.

[3] Yong Zhang, Jianli Dong, Cunhua Li, Zhaohui Ji, Junming Wu, "Review on Innovative Practice Teaching and Its Quality Evaluation System for Software Engineering Specialty”, Advanced Technology in Teaching, Advances in Intelligent and Soft Computing Volume 163, pp 389-397,2013.

[4] JinghongHu,Yongqing Zhang, ”College Innovative Talents Training Mode Based on Practical Teaching Reform”, Proceedings of the 2nd International Conference on Green Communications and Networks 2012 (GCN 2012): Vol. 2, pp. 507-513, 2012.

[5] Klaus Fichter, Severin Beucker, “The Evolution of Innovation Communities: Case Studies”, Innovation Communities, pp. 57-226, 2012. 